\title{
GAMBARAN LIKUIDITAS PROFITABILITAS DAN HARGA SAHAM PADA PERUSAHAAN OTOMOTIF YANG TERDAFTAR DI BEI
}

\author{
Youpick Endan Tricia \\ Universitas Pendidikan Indonesia \\ youpick.endan@student.upi.edu
Ahim Surachim
Universitas Pendidikan Indonesia
ahimsurachim@upi.edu \\ Eded Tarmedi \\ Universitas Pendidikan Indonesia \\ tarmedi@upi.edu
}

\begin{abstract}
ABSTRAK
Tujuan - menganalisis gambaran likuiditas, profitabilitas dan harga saham pada perusahaan otomotif.

Desain/metodologi/pendekatan -Metode penelitian ini menggunakan metode deskriftif. Objek dalam penelitian ini yaitu perusahaan otomotif yang terdaftar pada Bursa Efek Indonesia periode 2010-2016. Teknik pengumpulan data dengan data panel. Teknik analisis data dengan menggunakan teknik analisis regresi panel yaitu dengan bantuan Eviews 9 .

Temuan - Hasil penelitian menunjukkan bahwa : (1) Profitabilitas yang diukur menggunakan Return On Equity perusahan otomotif cenderung menurun. (2) Likuiditas yang diukur menggunakan Current Ratio perusahaan otomotif cenderung menurun. (3) Harga Saham perusahaan otomotif Menurun

Orisinalitas/nilai - Penelitian ini memberikan dasar untuk memahami isu-isu gambaran likuiditas, profitabilitas dan harga saham. Perbedaan penelitian ini dengan penelitian sebelumnya adalah pada objek, variabel, teori, Teknik Analisis data serta referensi yang digunakan oleh peneliti dengan peneliti sebelumnya.
\end{abstract}

Kata Kunci : Likuiditas, Profitabilitas, Current Ratio, harga saham, dan Return On Investment Tipe Artikel : Case Study

\begin{abstract}
Objectives - analyze the description of liquidity, profitability and stock prices in automotive companies. Design / methodology / approach - This research method uses descriptive method. Objects in this study are automotive companies listed on the Indonesia Stock Exchange period 2010-2016. Data collection techniques with panel data. Data analysis technique using panel regression analysis technique with the help of Eviews 9. Findings - The results show that: (1) Profitability measured using Return On Equity automotive companies tend to decrease. (2) Liquidity measured using Current Ratio of automotive companies tends to decrease. (3) Automotive company stock price decreased

Originality / value - This research provides a basis for understanding issues of liquidity, profitability and stock price. The difference of this research with previous research is on object, variable, theory, technique of data analysis and also reference which used by researcher with previous researcher.

Keywords: Liquidity, Profitability, Current Ratio, Stock Price, and Return On Investment

Article Type: Case Study

\section{PENDAHULUAN}

Pembangunan ekonomi pada setiap negara tergantung pada sektor keuangan dan pasar modal, sehingga pasar modal memiliki peranan yang sangat penting dalam bisnis internasional diseluruh dunia. (Suriani, Kumar, Jamil, \& Muneer, 2015). Pasar modal dapat menjadi peluang bagi investor untuk menanamkan

modalnya, hal tersebut sejalan dengan yang diungkapkan oleh Mondal \& Imran, (2011) bahwa pasar modal menjamin aliran sumber daya untuk peluang investasi yang paling produktif. Pendapat tersebut diperkuat oleh Brigham \& Daves, (2002) yang menyatakan bahwa tujuan pemilik perusahaan atau para pemegang saham atas investasi mereka adalah menciptakan harga saham bagi para pemegang saham. Setiap perusahaan
\end{abstract}


berusaha meningkatkan kinerjanya dengan menunjukkan prestasi yang ditunjukkan dengan peningkatan harga saham perusahaannya (Kussuma, Surachim, dan Tanuatmodjo, 2016).

Harga saham merupakan indikator penting dalam pembuatan keputusan di masa depan (Haroon, 2011). Salah satu cara perusahaan dalam memakmurkan pemegang saham adalah melalui maksimalisasi harga saham. (Susanto, 2012) Menurut Nurmalasari Indah (2009) Harga saham mencerminkan nilai dari suatu perusahaan. Jika perusahaan mencapai prestasi yang baik, maka saham perusahaan tersebut akan banyak diminati oleh para investor. Menurut Tabak (2006) Penurunan harga saham akan mendorong penurunan kekayaan investor dalam negeri. Sehingga akan menghambat tujuan perusahaan. Sejalan dengan hal tersebut Fenomena yang dialami perusahaan harus segera ditanggulangi sebab akan menghambat tujuan perusahaan yang mungkin bisa mengarah pada kehancuran perusahaan tersebut (Mulyadi, 2010).

Penurunan harga saham perusahaan otomotif yang terdaftar di BEI menjadi kondisi yang sangat mengkhawatirkan, karena sebagai perusahaan perusahaan yang sudah go public, para pemegang saham akan menarik investasi mereka dan mungkin banyak karyawan yang terkena Pemutusan Hubungan Kerja (PHK). Berikut adalah harga saham keuangan perusahaan otomotif, nilainya seperti yang tertera pada Tabel 1

\section{Tabel 1}

Nilai Harga Saham Pada Perusahaan Otomotif yang Terdaftar di BEI, Periode 2010-

\begin{tabular}{cc}
\multicolumn{2}{c}{ 2016 } \\
\hline $\begin{array}{c}\text { Tahun } \\
\text { Periode }\end{array}$ & $\begin{array}{c}\text { Nilai Harga } \\
\text { Saham }\end{array}$ \\
\hline 2010 & 9874 \\
2011 & 9716 \\
2012 & 4442 \\
2013 & 4192 \\
2014 & 4309 \\
2015 & 4039 \\
2016 & 2441
\end{tabular}

Sumber : Annual Report Perusahaan, 2018 (Diolah)

Berdasarkan Tabel 1.1 Rata-rata nilai harga saham perusahaan otomotif dapat dilihat mengalami fluktuasi yang cenderung mengalami penurunan Dapat dilihat pada tahun 2015, rata-rata harga saham perusaaan otomotif mengalami penurunan yang sangat signifikan dibandingkan dengan tahun-tahun sebelumnya. Pada tahun 2010 rata-rata harga saham otomotif berada pada nominal Rp 9.874 kemudian turun menjadi Rp 9.761 pada tahun 2011. Penurunan tersebut berlanjut pada tahun 2012 dan 2013, dimana turun kembali menjadi Rp 4.442 untuk tahun 2012 dan Rp. 4.192 pada tahun 2013. Pada tahun 2014 mengalami kenaikan harga saham sebesar Rp. 117 menjadi Rp. 4.309. Namun pada tahun 2015 mengalami penurunan sebesar Rp 1.868 menjadi 2.441. kemudian pada tahun 2016 mengalami penuruan sebesar Rp 1 menjadi 2440.

Penurunan tersebut cukup membahayakan, mengingat subsektor otomotif merupakan subsektor utama dan unggul serta menjadi cerminan sektor aneka industri itu sendiri, Apabila harga saham subsektor otomotif tersebut terus terjadi menurun maka akan berdampak negatif dan menjadi masalah bagi perusahaan-perusahaan didalamnya, karena harga saham ini berkaitan erat dengan ketertarikan investor, karena dengan menurunnya harga saham menunjukan bahwa kinerja perusahaannya kurang baik. Tinggi rendahnya nilai saham sebenarnya tercermin pada kinerja keuangan perusahaan. Jika suatu perusahaan memiliki kinerja keuangan yang baik maka investor akan menanamkan modalnya, karena dapat dipastikan akan memperoleh keuntungan dari penanaman modal tersebut, sebaliknya jika kinerja keuangan perusahaannya buruk, maka investor enggan menanamkan modalnya di perusahaan tersebut.

Menurut (Arifin, 2001:116) faktor-faktor yang mempengaruhi harga saham antara lain: kondisi fundamental perusahaan, hukum permintaan dan penawaran,tingkat suku bunga, kurs valuta asing, dana asing di bursa, indeks harga saham, news and rumors, dividen, laba perusahaan, dan faktor lain. Menurut Alwi bahwa faktor yang mempengaruhi harga saham terdiri dari faktor internal dan faktor eksternal (Iskandar $\mathrm{Z}, 2003: 87$ ), sejalan dengan hal tersebut menurut Arifin (2007:116) faktor-faktor yang mempengaruhi harga saham antara lain: kondisi fundamental perusahaan, hukum permintaan dan penawaran, tingkat suku bunga, kurs valuta asing, dana asing di bursa, indeks harga saham, news and rumors, dividen, laba perusahaan, dan faktor lain. Sejalan dengan hal tersebut (Jufrizen, 2012) 
mengungkapkan analisis fundamental atau Pendekatan fundamental berkaitan dengan penilaian kinerja perusahaan, tentang efektifitas dan efsiensi perusahaan mencapai sasarannya. Menurut Habib (2008:91) Kinerja Keuangan diukur dengan banyak indikator, salah satunya adalah analisis rasio keuangan. Gitman, et.al. (2010:72) banyak indikator yang digunakan untuk menentukan baik atau tidaknya kinerja keuangan perusahaan, antara lain likuiditas, profitabilitas, solvabilitas, aktivitas dan nilai pasar. Kenyataan yang terjadi dilapangan faktor fundamental lebih sering diteliti dibandingkan faktor ekstenal.

Persaingan usaha pada saat ini semakin lama semakin tinggi, sehingga setiap perusahaan harus mampu untuk mempertahankan kinerja perusahaan (Mulyadi dan Saktiawati, 2008). Menurut Habib (2008:91) Kinerja Keuangan diukur dengan banyak indikator, salah satunya adalah analisis rasio keuangan. Gitman, et.al. (2010:72) banyak indikator yang digunakan untuk menentukan baik atau tidaknya kinerja keuangan perusahaan, antara lain likuiditas, profitabilitas, solvabilitas, aktivitas dan nilai pasar. Kenyataan yang terjadi dilapangan faktor fundamental lebih sering diteliti dibandingkan faktor ekstenal. Dalam penelitian ini faktor fundamental yang digunakan dalam menentukan perubahan harga saham yaitu likuiditas dan profitabilitas. Penelitian ini hanya memilih faktor yang mempengaruhi harga saham, yaitu likuiditas menggunakan Current Ratio (CR) dan Profitabilitas menggunakan Return on Equity ( $R O E$ ) sebagai variabel bebas atau independent untuk diteliti dimana penurunan profitabilitas akan menekan pencapaian laba bersih industri dan pada akhirnya menurunkan imbal hasil yang dinikmati pemegang saham. Semakin rendah ROE ini, semakin kecil tingkat keuntungan yang diperoleh pemegang saham (Surahim dan Dintha, 2016). Berdasarkan latar belakang tersebut, maka tujuan penelitian ini adalah untuk mengetahui gambaran likuiditas, profitabilitas dan harga saham pada perusahaan otomotif yang terdaftar di BEI.

\section{KAJIAN PUSTAKA}

Likuiditas ini sering digunakan oleh perusahaan maupun investor untuk mengetahui tingkat kemampuan perusahaan dalam memenuhi kewajibannya. Kewajiban tersebut bersifat jangka pendek. Kewajiban jangka pendek itu seperti, membayar tagihan listrik, gaji pegawai, atau hutang yang telah jatuh tempo. Tetapi terkadang ada beberapa perusahaan tidak sanggup membayar hutang tersebut pada waktu yang telah ditentukan, dengan alasan perusahaan tidak memiliki dana yang cukup untuk menutupi hutang yang telah jatuh tempo tersebut. Irawati (2006) yang menyatakan bahwa likuiditas adalah kemampuan untuk membayar kewajiban yang jatuh tempo. Likuiditas adalah istilah keuangan yang menggabungkan jumlah modal yang tersedia untuk investasi (Rose, 2010). Rasio likuiditas mengukur kemampuan perusahaan dalam memenuhi kebutuhan kas ketika kebutuhan tersebut meningkat (Lyn, 2008:221). Sedangkan menurut Lamberg (2009) menyatakan bahwa " The liquidity of an asset means how quickly it can be transformed into cash. When fererring to company liquidity on usually means its ability to meet is current liabilities and is usually measured by different financial ratios". Jenis rasio yang digunakan dalam mengukur likuiditas salah satunya adalah current ratio atau rasio lancar. Current ratio yang rendah biasanya dianggap menunjukan terjadinya masalah dalam likuiditas, sebaliknya current ratio yang terlalu tinggi juga kurang bagus karena menunjukan banyaknya dana menganggur yang pada akhirnya dapat mengurangi kemampuan laba perusahaan (Sawir, 2009:10). Musthaq (2015) menyatakan bahwa rasio likuiditas meliputi 1) Current Ratio, 2) Quick Ratio, 3) Debt to Equity Ratio, 4) Interest Covorage Ratio, 5) Inventiry Turnover, 6) Creditors Turnover, dan 7) Debtors Turnover. Pada penelitian ini rasio yang digunakan untuk menghitung Likuiditas adalah Current Ratio. Menurut Kasmir (2012) Current Ratio menunjukkan tingkat keamanan (margin of safety) kreditor jangka pendek, atau kemampuan perusahaan untuk membayar hutang yang jatuh tempo. Current ratio yang terlalu tinggi menunjukkan kelebihan uang Kas atau aktiva lancar lainnya dibandingkan dengan yang dibutuhkan sekarang atau tingkat likuiditas yang rendah daripada aktiva lancar dan sebaliknya. Menurut (Brigham et al., 2009:93) pengukurannya dapat menggunakan rumus sebagai berikut:

$$
\text { Current Ratio }=\frac{\text { Current Assets }}{\text { Current Liability }}
$$

Profitabilitas menurut Kasmir (2012), adalah rasio untuk menilai kemampuan perusahaan dalam mencari keuntungan. Rasio ini juga memberikan ukuran tingkat efektivitas manajemen suatu perusahaan. Rasio profitabilitas digunakan untuk mengukur hasil akhir dari berbagai kebijakan dan keputusan manajemen dalam menjalankan perusahaan. Rasio ini 
menggambarkan tingkat efektifitas pengelolaan perusahaan oleh manajemen, oleh sebab itu akan diperhatikan oleh pemilik modal. Karena investor jangka panjang sangat berkepentingan dengan analisa profitabilitas ini misalnya bagi pemegang saham akan melihat keuntungan yang benar-benar akan diterima dalam bentuk dividen. Menurut Harahap (2009:305) "Rasio profitabilitas menggambarkan kemampuan perusahaan mendapatkan laba melalui semua kemampuan dan sumber yang ada seperti kegiatan penjualan, kas, modal, jumlah karyawan, jumlah cabang dan sebagainya". Menurut L. J. Gitman dan Joehnk (2010:79-82) macam-macam rasio profitabilitas adalah:

1. Common Size Income Statement

Sebuah laporan laba rugi dimana setiap item dinyatakan sebagai persentase penjualan.

2. Gross Profit Margin

Mengukur persentase setiap sisa penjualan yang tersisa setelah perusahaan membayar barangnya.

3. Operating Profit Margin

Mengukur presentase setiap sisa penjualan yang tersisa setelah semua biaya dan biaya selain bunga, pajak, dan saham preferen dikurangkan, "keuntungan murni" yang diperoleh dari setiap dolar penjualan.

\section{Net Profit Margin}

Mengukur persentase setiap sisa penjualan yang tersisa setelah semua biaya dan pengeluaran, termasuk bunga, pajak, dan dividen saham preferen, telah dikurangkan.

5.Earning per Share (EPS)

Merupakan jumlah dolar yang diterima atas nama setiap saham biasa yang beredar - bukan jumlah pendapatan yang benar-benar didistribusikan kepada pemegang saham.

6. Return on Total Assets (ROA)

Mengukur keseluruhan efektivitas manajemen dalam menghasilkan keuntungan dengan aset yang ada, juga disebut return on investment.

7. Return on Equity (ROE)

Mengukur laba yang diperoleh dari investasi pemegang saham biasa di perusahaan.

Pada penelitian ini rasio yang digunakan untuk menghitung Profitabilitas adalah Return on Equity pengukurannya dapat menggunakan rumus sebagai berikut:

Return on Equity $(\mathrm{ROE})=\frac{\text { Earning after taxes }}{\text { Total equity }}$

Harga saham adalah nilai saham yang ditentukan oleh kekuatan penawaran jual beli saham pada mekanisme pasar tertentu dan juga merupakan harga jual dari investor yang satu ke investor lainnya. Menurut Rusdin (2013) Harga saham ditentukan menurut hukum permintaan penawaran atau kekuatan tawar menawar. Makin banyak orang yang ingin membeli, maka harga saham tersebut cenderung naik. Sebaliknya, makin banyak orang yang menjual saham., maka saham tersebut akan bergerak turun. Menurut E. Brigham \& Houston (2011) Harga saham adalah nilai pasar dari selembar saham perusahaan, sedangkan menurut Darmadji \& Fakhruddin (2012) Harga yang terjadi dibursa pada waktu tertentu. Harga saham bisa berubah naik atau pun turun dalam hitungan waktu yang begitu cepat. Ia dapat berubah dalam hitungan menit bahkan dapat berubah dalam hitungan detik. Hal tersebut dimungkinkan karena tergantung dengan permintaan dan penawaran antara pembeli saham dengan penjual saham. Menurut Iskandar $\mathrm{Z}$ (2007), faktor-faktor yang mempengaruhi pergerakan harga saham yaitu:

1. Faktor Internal yaitu:

1) Pengumuman tentang pemasaran, produksi, penjualan seperti pengiklanan, rincian kontrak, perubahan harga, penarikan produk baru, laporan produksi, laporan keamanan produk, dan laporan penjualan.

2) Pengumuman pendanaan (financing announcements), seperti pengumuman yang berhubungan dengan ekuitas dan hutang.

3) Pengumuman badan direksi manajemen (management board of director announcements) seperti perubahan dan pergantian direktur, manajemen, dan struktur organisasi.

4)Pengumuman pengambilalihan diversifikasi, seperti laporan merger, investasi ekuitas, laporan take over oleh pengakuisisian dan diakuisisi.

5) Pengumuman investasi (investment announcements), seperti melakukan ekspansi pabrik, pengembangan riset dan penutupan usaha lainnya.

6) Pengumuman ketenagakerjaan (labour announcements), seperti negoisasi baru, kontrak baru, pemogokan dan lainnya.

7) Pengumuman laporan keuangan perusahaan, seperti Earning Per Share (EPS), Dividen Per Share (DPS), Price Earning Ratio, Net Profit Margin, Return on Equity (ROE), Current Ratio (CR), dan lain-lain.

2. Faktor Eksternal yaitu:

1) Pengumuman dari pemerintah seperti 2perubahan suku bunga tabungan dan deposito, kurs valuta asing, inflasi, serta berbagai regulasi dan deregulasi ekonomi yang dikeluarkan oleh pemerintah.

2) Pengumuman hukum (legal announcements), seperti tuntutan karyawan terhadap perusahaan atau terhadap manajernya dan tuntutan perusahaan terhadap manajernya.

3) Pengumuman industri sekuritas (securities announcements), seperti laporan pertemuan tahunan, insider trading, volume atau harga saham perdagangan, pembatasan/penundaaan trading.

4) Gejolak politik dalam negeri dan fluktuasi nilai tukar juga merupakan faktor yang berpengaruh 
signifikan pada terjadinya pergerakan harga saham di bursa efek suatu negara.

5) Berbagai isu baik dari dalam dan luar negeri.

Pada umumnya nilai dari suatu saham diklasifikasikan menjadi empat konsep, yaitu nilai nominal, nilai buku per lembar saham, nilai pasar, dan nilai intrinsik. nilai dari suatu saham dengan empat konsep tersebut sebagai berikut:

\section{Nilai Nominal}

Merupakan nilai per lembar saham yang berkaitan dengan akuntansi dan hukum. Nilai ini diperlihatkan pada neraca perusahaan dan merupakan modal disetor penuh dibagi dengan jumlah saham yang sudah diedarkan.

2. Nilai Buku Per Lembar Saham

Menunjukan nilai aktiva bersih per lembar saham yang merupakan nilai ekuitas dibagi dengan jumlah lembar saham.

3. Nilai Pasar

Nilai suatu saham yang ditentukan oleh permintaan dan penawaran yang terbentuk di bursa saham.

4. Nilai Intrinsik

Merupakan harga wajar saham yang mencerminkan harga saham yang sebenarnya. Nilai Intrinsik ini merupakan nilai sekarang dari semua faktor fundamental di masa mendatang (yang berasal dari capital gain dan dividen).

\section{METODE PENELITIAN}

I Wirantha, (2006:39) mengemukakan bahwa, objek penelitian (variabel penelitian) adalah karakteristik tertentu yang mempunyai nilai, skor atau ukuran yang berbeda untuk unit atau individu yang berbeda atau merupakan konsep yang diberi lebih dari satu nilai. Berdasarkan definisi tersebut, objek penelitian dalam penelitian ini adalah likuiditas, profitabilitas dan harga saham perusahaan otomotif di Indonesia tahun 2010-2016. Adapun yang menjadi variabel independen dalam penelitian ini adalah likuiditas yang diukur dengan $\mathrm{CR}$ dan profitabilitas yang diukur dengan ROE, sedangkan untuk variabel dependennya adalah harga saham.

Penelitian ini dilakukan untuk mengetahui bagaimana gambaran likuiditas profitabilitas dan harga saham Perusahaan Sub Sektor otomotif yang terdaftar di Bursa Efek Indonesia Periode 20102016. Sesuai dengan metode penelitian yang digunakan, untuk menghitung likuiditas (variabel $\mathrm{X} 1$ ), profitabilitas (variabel X2) dan harga saham (variabel Y), yaitu dengan cara mendeskripsikan setiap indikator-indikator variabel tersebut dari hasil pengumpulan data yang didapat. Adapun cara untuk menghitung indikator dari setiap variabel yang digunakan dalam penelitian ini adalah sebagai berikut:

Mengetahui Current Ratio perusahaan menggunakan perhitungan

\section{Current Ratio $=\frac{\text { Current Assets }}{\text { Current Liability }}$}

Menghitung profitabilitas dengan Ratio on Equity (ROE)

$$
\begin{gathered}
\text { Return on Equity }(\mathrm{ROE})=\frac{\text { Earning after taxes }}{\text { Total equity }} \\
\text { Menghitung harga saham dengan }
\end{gathered}
$$
indikator closing price tahunan.

Penelitian dilakukan di Perusahaan Sub Sektor otomotif yang terdaftar di Bursa Efek Indonesia Periode 2010-2016. Penelitian ini merupakan penelitian kuantitatif dengan menggunakan desain data panel. Data panel adalah sekumpulan data pengamatan yang diperoleh dari kombinasi data time series dan data cross section. Dengan kata lain data panel yakni sejumlah variabel yang di observasi atas sejumlah kategori dan dikumpulkan dalam satu jangka waktu tertentu. Berdasarkan objek penelitian di atas, maka akan dianalisis mengenai pengaruh likuiditas dan profitabilitas terhadap harga saham pada perusahaan otomotif yang terdaftar di BEI tahun 2010-2016.

Berdasarkan tingkat penjelasan dan bidang penelitian, maka jenis penelitian ini adalah penelitian deskriptif. menurut Zuriah (2009:47) menyatakan bahwa metode penelitian deskriptif adalah penelitian yang diarahkan untuk memberikan gejala-gejala, fakta-fakta, atau kejadian-kejadian secara sistematis dan akurat, mengenai sifat-sifat populasi atau daerah tertentu. penelitian deskriptif bertujuan untuk memecahkan masalah-masalah aktual yang dihadapi sekarang dan untuk mungumpulkan data atau informasi guna disusun, dijelaskan dan dianalisis. Tujuan deskriptif dalam penelitian ini adalah untuk mengetahui gambaran likuiditas, profitabilitas dan harga saham pada perusahaan otomotif. Metode penelitian yang digunakan adalah metode explanatory survey. Explanatory survey dilakukan untuk mengeksplorasi situasi masalah, yaitu untuk mendapatkan ide-ide dan wawasan kedalam masalah yang dihadapi manajemen atau para peneliti tersebut (Maholtra, 2010:96).

Operasionalisasi variabel diperlukan untuk menentukan jenis dan indikator dari variabelvariabel yang terkait dalam penelitian ini. Variabel adalah Variabel adalah sesuatu yang dapat digunakan untuk membedakan atau merubah nilai, sebagai sinonim dari konstruk yang dinyatakan dengan nilai atau angka (Wijaya, 2013:13). Operasionalisasi variabel bertujuan untuk menentukan jenis dan indikator variabel terkait.

Untuk mendapatkan data yang relevan dengan hipotesis penelitian, dilakukan pengukuran terhadap variabel-variabel penelitian. Variabel yang digunakan dalam penelitian ini adalah variabel independen dan variabel dependen. 
Menurut Umar (2007) variabel independen adalah variabel yang menjelaskan atau mempengaruhi variabel yang lain, sedangkan variabel dependen adalah variabel yang dijelaskan atau yang dipengaruhi variabel independen.

Dalam penelitian ini terdapat dua variabel yang akan diteliti, yaitu:

\section{Variabel bebas $(\mathrm{X})$}

Variabel independen adalah variabel yang dimanipulasi oleh peneliti dan yang efeknya diukur dan dibandingkan pada variabel dependen. Variabel bebas dalam penelitian ini adalah Likuiditas dan Profitabilitas.

\section{Variabel terikat $(\mathrm{Y})$}

Variabel dependen adalah variabel yang dipengaruhi atau yang menjadi akibat karena adanya variabel bebas. Variabel terikat dalam penelitian ini adalah Harga Saham.

Populasi yang diambil dalam penelitian ini adalah laporan keuangan perusahaan sub sektor otomotif yang terdaftar di BEI periode 2010-2016. Sampel pada penelitian ini adalah laporan laba rugi perusahaan subsektor otomotif yang terdaftar di BEI periode 2010-2016. Penelitian ini menggunakan teknik nonprobability sampling dengan menggunakan sampling purposive dalam penentuan sampelnya. Menurut Sugiyono (2014:120), nonprobability sampling adalah teknik pengambilan sampel yang tidak memberi peluang/ kesempatan sama bagi setiap unsur atau anggota populasi untuk dipilih menjadi sampel. Sedangkan sampling purposive adalah teknik penentuan sampel dengan pertimbangan tertentu.

Pengambilan sampel dalam penelitian ini mengikuti beberapa asumsi/kriteria berikut:

1. Perusahaan yang diteliti adalah perusahaan yang konsisten listing di Bursa Efek Indonesia selama periode penelitian yaitu tahun 2010-2016

2. Perusahaan otomotif yang memiliki laporan keuangan tahun 2010-2016

3. Perusahaan otomotif yang memiliki informasi mengenai likuiditas, profitabilitas dan harga saham perusahaan.

Teknik pengumpulan data yang digunakan adalah teknik dokumentasi yaitu teknik yang memperoleh data dengan cara mempelajari dokumen yang berkaitan dengan seluruh data yang diperlukan dalam penelitian ini. Sedangkan teknik analisis data yang dilakukan adalah analisis deskriptif menggunakan rumus perhitungan likuiditas, profitabilitas dan harga saham.

HASIL PENELITIAN DAN PEMBAHASAN Gambaran Likuiditas

Likuiditas ialah kemampuan perusahaan membayar kewajiban-kewajiban jangka pendek yang harus dipenuhi. Apabila perusahaan dapat memenuhi kewajiban jangka pendeknya tepat waktu, maka perusahaan tersebut dapat dikatakan perusahaan yang likuid. Sebaliknya, apabila perusahaan tidak bisa membayar maka dapat dikatakan perusahaan dalam keadaan ilikuid. Likuiditas adalah istilah keuangan yang menggabungkan jumlah modal yang tersedia untuk investasi (Stephen G and Rose, 2010:78).

Dalam penelitian ini rasio likuiditas yang akan digunakan yaitu current ratio (CR). Current ratio merupakan rasio keuangan yang populer digunakan untuk menguji likuiditas perusahaan (juga disebut sebagai posisi modal saat ini atau bekerja) dengan menurunkan proporsi aktiva lancar yang tersedia untuk menutupi kewajiban lancar (Nguyen Hoang dkk, 2014). Current ratio menunjukkan sejauhmana aktiva lancar menutupi kewajiban-kewajiban lancar. Semakin besar perbandingan aktiva lancar dan kewajiban lancar semakin tinggi kemampuan perusahaan menutupi kewajiban jangka pendeknya (Munawir, 2007:72). Penelitian yang dilakukan pada Laporan Keuangan Subsektor Otomotif periode 2010-2016, menunjukkan temuan teoritis yang membuktikan bahwa likuiditas yang diukur dengan current ratio dari tahun ke tahun mengalami fluktiatif, namun cenderung mengalami penurunan. Nilai CR dari perusahaan subsektor otomotif setiap tahunnya tidak mencapai batas minimum nilai $\mathrm{CR}$. Penurunan nilai CR diakibatkan oleh nilai hutang lancar yang terus meningkat tanpa diseimbangi dengan peningkatan aktiva lancar. Dampak yang akan diterima apabila nilai $\mathrm{CR}$ tersebut terus mengalami penurunan ialah kepercayaan investor ikut menurun.

Berikut Hasil dari pengolahan data mengenai kategori variabel Likuiditas terlihat pada Tabel 2 berikut ini:

Tabel 2

Rata-rata Likuiditas (Current Ratio) Perusahaan Subsektor otomotif yang Terdaftar di BEI Periode 2010-2016

\begin{tabular}{cc}
\hline $\begin{array}{c}\text { Tahun } \\
\text { Periode }\end{array}$ & $\begin{array}{c}\text { Rata-rata Current } \\
\text { Ratio }\end{array}$ \\
\hline 2010 & 164.65 \\
2011 & 168.64 \\
2012 & 161.08 \\
2013 & 175.94 \\
2014 & 164.55 \\
2015 & 136.89
\end{tabular}


2016

152.84

Sumber : Annual Report Perusahaan, 2018 (Diolah)

Pada Tabel 2 dapat dilihat perkembangan likuiditas (current ratio) perusahaan subsektor otomotif dari tahun 2010 sampai 2016 Nilai Current Ratio (CR) perusahaan otomotif tahun 2010-2016 mengalami fluktuatif yang cenderung menurun. Rata-rata Current Ratio di tahun 2010 ke 2011 mengalami peningkatan sebesar $2.4 \%$ dari angka 164,65 ke angka 168,64. peningkatan CR tertinggi dialami oleh PT. Indospring yaitu sebesar $86,8 \%$ dari angka 128.67 ke angka 240,4. Kemudian rata-rata $\mathrm{CR}$ perusahaan subsektor otomotif di tahun 2011 ke 2012 mengalami penurunan sebesar $4.5 \%$ dari angka 168,64 ke angka 161.08, pada tahun tersebut penurunan CR tertinggi dialami oleh PT. Selamat Sempurna yaitu sebesar $28.4 \%$ dari angka 271.58 ke angka 194,42. Namun rata-rata $\mathrm{CR}$ perusahaan subsektor otomotif ditahun 2012 ke 2013 mengalami kenaikan sebesar 9,2\% dari angka 161,08 ke 175,94. Namun setelah kenaikan yang cukup signifikan tahun 2014 dan 2015.

Tahun 2015 mengalami penurunan sebesar 22.2\% dari tahun 2013 dan merupakan titik terendah selama 7 tahun dari 175,94 menjadi 136.89. Kemudian rata-rata CR perusahaan subsektor otomotif di tahun 2015 ke 2016 mengalami kenaikan sebesar $11.6 \%$ dari angka 136.89 ke angka 152.84, pada tahun tersebut kenaikan CR tertinggi dialami oleh PT. Selamat Sempurna yaitu sebesar 78,6\% dari angka 160.08 ke angka 286. Dapat dilihat bahwa rata-rata current ratio perusahaan mengalami fluktuatif yang cenderung menurun. Penurunan nilai CR menggambarkan menurunnya kemampuan perusahaan dalam membayar kewajiban jangka pendeknya. Dapat dilihat rata-rata $\mathrm{CR}$ dari perusahaan otomotif mengalami penurunan selama 2 tahun dari 2014-2015. Hal ini dapat mengakibatkan mengurangi minat investor dalam menanamkan saham ke perusahaan di subsektor otomotif ini dengan kata lain, CR dapat memberikan pengaruh terhadap harga saham yang dinilai oleh investor. Jika diproyeksikan, pertumbuhan rata-rata likuidtias (current ratio) pada perusahaan subsektor otomotif yang terdaftar di Bursa Efek Indonesia periode 2010-2016 Untuk lebih memperjelas dapat dilihat pada gambar 1

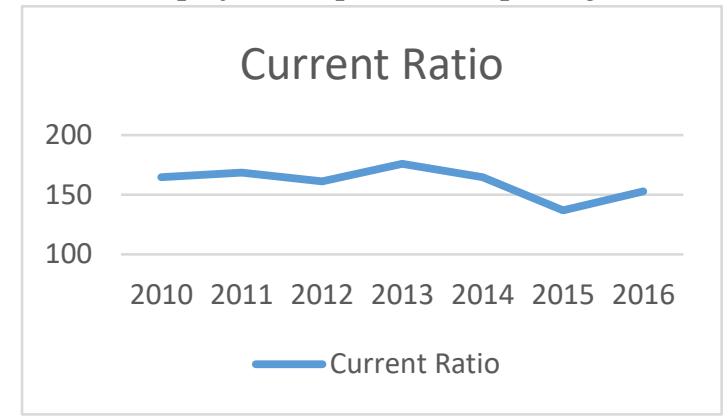

Sumber : Annual Report Perusahaan, 2018 (Diolah)

\section{Gambar 1}

Rata-rata Likuiditas (Current Ratio)

Perusahaan Subsektor otomotif yang

Terdaftar di BEI Periode 2010-2016

Likuiditas perusahaan yang tinggi akan membuat investor kurang tertarik untuk menanamkan sahamnya, karena hal tersebut menandakan bahwa tingkat hutang perusahaan tinggi. Sebaliknya, jika likuiditas perusahaan rendah, maka investor akan tertarik untuk menanamkan sahamnya, karena hal tersebut menandakan bahwa perusahaan dapat mengoptimalkan modal perusahaan dengan baik.

Namun, hasil penelitian ini didukung oleh penelitian sebelumnya yang dilakukan oleh Erawati (2015) dan Susanto (2012), yang menyatakan bahwa Currrent Ratio (CR) tidak berpengaruh dan signifikan terhadap harga saham.

Berdasarkan gambar 1 tersebut dapat dilihat bahwa perkembangan Current Ratio terdefinisikan fluktiatif yang cenderung menurun.

Berdasarkan penjelasan diatas CR perusahaan subsektor otomotif yang mengalami fluktuatif yang cenderung turun dari tahun ke tahun.

\section{Gambaran Profitabilitas}

Untuk mengetahui seberapa baik keberhasilan perusahaan dalam menghasilkan laba diperlukan satu ukuran, ukuran yang digunakan adalah profitabilitas. Profitabilitas merupakan alat ukur perusahaan bagaimana menghasilkan keuntungan bagi perusahaan. Profitabilitas ini digunakan untuk melihat kemampuan perusahaan dalam mengoptimalkan seluruh yang dimiliki oleh perusahaan untuk menghasilkan laba. Menurut Agus Sartono (2010:122), menyatakan bahwa "Profitabilitas adalah kemampuan perusahaan memperoleh laba dalam hubungannya dengan penjualan, total aktiva maupun modal sendiri”.

Alat ukur yang digunakan dalam penelitian ini adalah Return on Equity (ROE). Menurut Lukman Syamsudin (2004:64) Return on Equity 
(ROE) adalah salah satu alat pengukuran dari penghasilan (income) yang tersedia bagi pemilik perusahaan atas modal sendiri yang mereka investasikan didalam perusahaan. Selain itu, menurut Sutrisno (2009:253)

Hasil pengolahan data mengenai variabel profitabilitas terlihat pada Tabel 3 berikut ini :

Tabel 3

Profitabilitas Perusahaan Subsektor otomotif yang Terdaftar di BEI Periode 2010-2016

\begin{tabular}{cc}
\hline $\begin{array}{c}\text { Tahun } \\
\text { Periode }\end{array}$ & $\begin{array}{c}\text { Rata-rata Return } \\
\text { on Equity }\end{array}$ \\
\hline 2010 & 21,04 \\
2011 & 15,28 \\
2012 & 15,85 \\
2013 & 11,66 \\
2014 & 9,32 \\
2015 & 4,64 \\
2016 & $-2,67$
\end{tabular}

Sumber : Annual Report Perusahaan, 2017 (Diolah)

Tabel 3 menunjukkan perubahan perkembangan rata-rata Return on Equity (ROE) subsektor otomotif tahun 2010 sampai dengan tahun 2016. Berdasarkan data tersebut, rata-rata ROE di tahun 2010 ke 2011 mengalami penurunan sebesar $27.3 \%$ dari angka 21,04 ke angka 15.28. Kemudian rata-rata ROE perusahaan subsektor otomotif di tahun 2011 ke 2012 mengalami kenaikan sebesar 4\% dari angka 15.28 ke angka 15.85. Namun pada tahun 2013 hingga 2016 perkembangan rata-rata Return on Equity subsektor otomotif mengalami penurunan secara terus menerus. Penurunan ini sebesar $26 \%$ pada tahun 2013 dari angka 15,85 ke angka 11,66 sedangkan pada tahun 2014 penurunan ROE sebesar 20\% dari angka 11,66 ke angka 9,32 dan pada tahun 2015 penurunan ROE sebesar $50 \%$ dari angka 9,32 ke angka 4,64 kemudian penurunan terbesar yaitu pada tahun 2016 sebesar $157 \%$ dari angka 4,64 ke angka -2.67 .

Untuk lebih memudah melihat pergerakan ROE dapat dilihat pada gambar 2

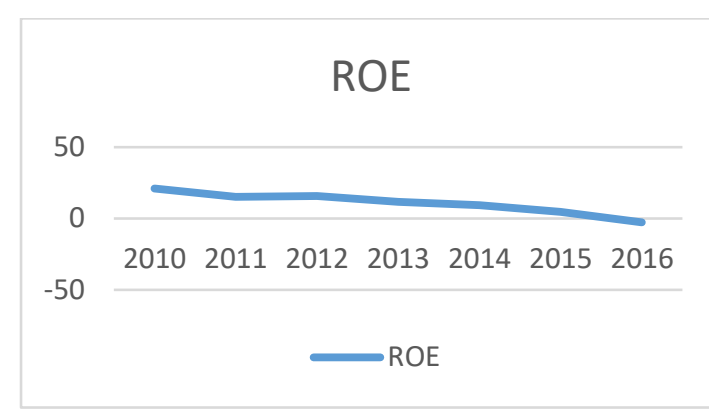

Sumber : Annual Report Perusahaan, 2018 (Diolah)

Gambar 2

Harga Saham Pada Perusahaan Otomotif yang Terdaftar di BEI, Periode 2010-2016

Berdasarkan gambar 2 tersebut dapat dilihat bahwa perkembangan ROE terdefinisikan menurun. Penurunan nilai ROE menggambarkan menurunnya kemampuan perusahaan dalam meningkatkan labanya. Dapat dilihat rata-rata ROE dari subsektor otomotif penurunan selama 4 tahun terakhir yang cukup signifikan dari 20132016. Hal ini dapat mengurangi minat investor dalam menanamkan saham ke perusahaan di subsektor otomotif ini. Investor menilai kinerja perusahaan itu berdasarkan tingkat pertumbuhan laba dengan melihat pertumbuhan ROE. Dengan kata lain, ROE dapat memberikan pengaruh terhadap harga saham yang dinilai oleh investor.

\section{Gambaran Harga saham}

Menurut Rusdin (2013:66) menjelaskan bahwa harga saham ditentukan menurut hukum permintaan-penawaran atau kekuatan tawarmenawar. Semakin banyak orang yang ingin membeli, maka harga saham tersebut cenderung bergerak naik. Sebaliknya, semakin banyak orang yang ingin menjual saham, maka saham tersebut akan bergerak turun.

Harga saham cenderung menjadi tinggi ketika perusahaan mempunyai banyak peluang bagi investor yang menguntungkan, karena peluang laba berarti pendapatan masa depan yang lebih tinggi untuk pemegang saham. Harga saham yang terlalu rendah sering ditafsirkan bahwa kinerja perusahaan kurang baik sedangkan jikaharga saham terlalu tinggi akan membatasi kemampuan investor untuk membelinya. Hal ini akan berpengaruh terhadap permintaan dan penawaran saham yang pada akhirnya akan membentuk harga suatu saham. Harga saham dalam penelitian ini adalah harga saham penutupan (closing price) pada setiap kuartal.

Hasil pengolahan data mengenai variabel harga saham terlihat pada Tabel 4 berikut ini:

\section{Tabel 1}

Harga Saham Pada Perusahaan Otomotif yang Terdaftar di BEI, Periode 2010-2016 


\begin{tabular}{cc}
\hline $\begin{array}{c}\text { Tahun } \\
\text { Periode }\end{array}$ & $\begin{array}{c}\text { Nilai Harga } \\
\text { Saham }\end{array}$ \\
\hline 2010 & 9874 \\
2011 & 9716 \\
2012 & 4442 \\
2013 & 4192 \\
2014 & 4309 \\
2015 & 4039 \\
2016 & 2441 \\
\hline
\end{tabular}

Sumber : Annual Report Perusahaan, 2018 (Diolah) Tabel 4 dapat dilihat pergerakan rata-rata harga saham pada perusahaan-perusahaan subsektor otomotif menurun secara terus menerus dalam dua tahun terakhir. Pada tahun 2010 rata-rata harga saham otomotif berada pada angka Rp 9874, harga saham tertinggi terjadi pada PT. Astra International Tbk yaitu sebesar Rp 54.550, sedangkan harga saham terendah terjadi pada PT. Prima Aloy Steel Tbk yaitu sebesar Rp 93. Kemudian pada tahun 2011 turun sebesar 1,7\% dari Rp 9874 menjadi Rp 9716. Kemudian pada tahun 2012 hingga 2013 rata rata harga saham perusahaan otomotif terus menurun sebesar $57 \%$ dari tahun 2011 dan 5\% dari tahun 2012 yakni mencapai angka 4192 pada tahun 2013. Namun pada tahun 2014 rata rata harga saham perusahaan otomotif mengalami kenaikan sebesar 2,8\% dari tahun 2013 dari angka 4192 menjadi 4309. Kemudian pada tahun 2015 harga saham perusahaan otomotif kembali mengalami penurunan dari 4039 menjadi 2441. Dan pada tahun 2016 kembali mengalami penurunan sebesar 1 angka dari tahun sebelumnya menjadi 2440.

Perkembangan harga saham perusahaan otomotif yang mengalami fluktuatif dari tahun ketahun hal ini cukup menarik mengingat jika harga saham perusahaan tersebut lebih banyak mengalami penurunan, maka akan berdampak negatif bagi perusahaan itu sendiri karena harga saham ini berkaitan erat dengan ketertarikan investor untuk berinvestasi pada suatu perusahaan dalam suatu industri. Semakin tinggi harga saham suatu perusahaan maka semakin besar pula return yang bisa diperoleh para investor. Dalam hal ini artinya jika perusahaan-perusahaan pada subsektor otomotif memiliki harga saham yang rendah dan cenderung menurun maka calon investor enggan untuk menanamkan modalnya karena setiap investor menginginkan return yang besar (Tandelilin, 2010:102)

\section{KESIMPULAN DAN REKOMENDASI}

Berdasarkan hasil penelitian yang telah dilakukan menggunakan analisis deskriptif dengan rumus perhitungan likuiditas, Profitabilitas dan harga saham dapat diambil kesimpulan bahwa likuiditas perusahaan subsektor otomotif yang terdaftar di BEI periode 2010-2016 bersifat fluktuatif yang cenderung menurun. Sementara profitablitas perusahaan subsektor otomotif yang terdaftar di BEI periode 2010-2016 bersifat fluktuatif yang cenderung menurun kinerja yang cenderung menurun ditunjukkan dengan angka ROE yang semakin rendah. Sedangkan harga saham perusahaan subsektor otomotif yang terdaftar di BEI periode 2010-2016 cenderung menurun.

Adanya penelitian ini diharapkan dapat membantu peneliti berikutnya dalam melakukan penelitian mengenai likuiditas, profitablitas dan harga saham dengan menggunakan perhitungan yang berbeda, sumber teori yang lebih beragam, objek yang berbeda, karena masih banyaknya keterbatasan dalam penelitian ini, khususnya yang berkaitan dengan metode penelitian dan teknik pengumpulan data.

Penelitian ini diharapkan dapat membantu perusahaan untuk melakukan analisis bagaimana kondisi likuiditas, profitablitas dan harga saham perusahaan subsektor otomotif yang terdaftar di BEI periode 2010-2016. Sehingga perusahaan dapat memperbaiki kinerja yang kurang serta mempertahankan bahkan meningkatkan kinerja mereka yang sudah dianggap baik.

\section{DAFTAR PUSTAKA}

Arifin, A. (2001). Membaca Saham. Yogyakarta: Andi.

Arifin, A. (2007). Membaca Saham (3rd ed.). Yogyakarta: Andi.

Brigham, E. F., \& Daves, P. R. . (2002). Intermediate Financial Management (7th ed.). Singapore: Thomson South-Western.

Brigham, E., \& Houston, J. F. (2011). DasarDasar Manajemen Keuangan (2nd ed.). Jakarta: Salemba Empat.

Brigham, Eugene F, \& Houston, J. J. (2009). Dasar-Dasar Manajemen Keuangan. (A. A. Yulianto, Ed.) (Kesepuluh). Jakarta: Salemba Empat.

Darmadji, T., \& Fakhruddin, M. H. (2012). Pasar Modal di Indonesia Pendekatan Tanya Jawab. Jakarta: Salemba Empat.

Gitman, L. j., \& Joehnk, M. D. (2010). Fundamentals of Investing (11th ed.). Boston: Prentice Hall.

Gitman, L. J., \& Joehnk, M. D. (2010). Fundamental Of Investing, 9th edition (11th ed.). Boston: Prentice Hall.

Habib, A. (2008). Kiat Jitu Peramalan Saham. 
Jakarta: Gramedia Pustaka Utama.

Harahap, S. S. (2009). Analisis kritis atas laporan keuangan. Jakarta: Raja Grafindo Persada.

Haroon, M. A. (2011). Corporate Fundamentals anhare Price Behavior. Interdisciplinary Journal of Contemporary Research in Business. Vol. 3, No.3. (Vol. 3).

I Wirantha, M. (2006). Metodologi Penelitian Sosial Ekonomi. Yogyakarta: C.V Andi Offset.

Irawati, S. (2006). Manajemen Keuangan. Bandung: Pustaka.

Iskandar Z, A. (2003). Pasar Modal, Teori dan Aplikasi. Jakarta: Nasindo Internusa.

Jufrizen. (2012). Pengaruh Rasio Profitabilitas Terhadap Harga Saham pada Perusahaan yang Tercatat dalam LQ45 di Bursa Efek Indonesia. Jurnal Visioner \& Strategis, 1(September), 197-212.

Kasmir. (2012). Analisis Laporan Keuangan. Jakarta: Rajawali Pers.

Kussuma, P., Surachim, A., \& Tanuatmodjo, H. (2016). DAMPAK TINGKAT PROFITABILITAS DAN NILAI PASAR PADA PERGERAKAN, 1(2), 97-103.

Lamberg, S. (2009). Study of the Adaption of Liquidity Strategies in a Financial Crisis, 8.

Lyn, M. F. \& A. O. (2008). Understanding Financial Statment (7th ed.). New Jerey: Prentice Hall.

Maholtra, K. N. (2010). Marketing Reseach: An Applied Orientation Sixth Ed Pearson Education (Sixth edit). Pearson Education.

Mondal, S. A., \& Imran, M. S. (2011). Determinants of Stock Price : A Case Study On Dhaka Stock Exchange.

Mulyadi, H. (2010). Pengaruh Motivasi dan Kompetensi Kerja Terhadap Produktivitas Kerja Karyawan pada PT. Galamedia Bandung Perkasa. Manajerial, 9(17), 97111.

Mulyadi, H., \& Saktiawati, D. (2008). Pengaruh Brand Personality Terhadap Loyalitas Pelanggan Shampo Sunsilk (Survei pada mahasiswi FPIPS UPI Bandung Angkatan 2004-2006). Journal Of Business Management \& Entrepreneur Education, 7(13), 20-32.

Musthaq, H. (2015). Trade off between Liquidity and Profitability. International Journal of
Scientific Research and Management, 3(5), 2015.

Nurmalasari Indah. (2009). Analisis Pengaruh Rasio Profitabilitas Terhadap Harga Saham Emiten LQ45 yang Terdaftar di Bursa Efek Indonesia. Analisis Pengaruh Ratio Profitabilitas Terhadap Harga Saham Emitan lq45 Yang Terdaftar Di Bursa Efek Indonesia. Retrieved from http://www.gunadarma.ac.id/library/articles /graduate/economy/2009/Artikel_20205630 .pdf

Rose, S. G. C. (2010). Banking and Financial Marketing. New York: Mc Grow Hill.

Rusdin. (2013). rusdin.pdf (2nd ed.). Bandung: ALFABETA.

Sawir, A. (2009). Analisa Kinerja Keuangan dan Perencanaan keuangan Perusahaan. Jakarta: PT. Gramedia Pustaka Utama.

Surahim, A., \& Dintha, R. (2016). Pengaruh Capital Structure Dan Working Capital Management Terhadap Profitabilitas. Journal of Business Management and Enterpreneurship Education, 1(1), 42-46.

Suriani, S., Kumar, M. D., Jamil, F., \& Muneer, S. (2015). International Journal of Economics and Financial Issues Impact of Exchange Rate on Stock Market Impact of Exchange Rate on Stock Market. International Journal of Economics and Financial Issues, 5(October), 385-388.

Susanto, A. S. (2012). Pengaruh Likuiditas, Profitabilitas, Solvabilitas, Dan Ukuran Perusahaan Terhadap Harga Saham Perusahaan Farmasi Di Bei. Jurnal Akuntansi, 1(1). Retrieved from http://ejournal.unesa.ac.id/

Tabak, B. M. (2006). The dynamic relationship between stock prices and exchange rates:evidence for Brazil. Working Paper Series, (124), 1-37. https://doi.org/10.1142/S021902490600397 4

Tandelilin, E. (2010). Analisis Investasi dan Manajemen Portofolio. Yogyakarta: BPFE Yogyakarta.

Zuriah. (2009). Metodologi Penelitian Sosial Dan Pendidikan. Jakarta: Bumi Aksara 